\title{
Islamic Cultural Symbol in "Tabur Beras Kuning” Tradition in the Wedding Ceremony in Malang
}

\author{
Syamsudin ${ }^{1, *} \&$ Rina Sari $^{1}$ \\ ${ }^{1}$ English Letters Department, Humanities Faculty, Universitas Islam Negeri Maulana Malik \\ Ibrahim of Malang Indonesia, Indonesia \\ *Corresponding author: English Letters Department, Humanities Faculty, Universitas Islam \\ Negeri Maulana Malik Ibrahim of Malang Indonesia, Indonesia. E-mail: \\ syamsudinuin69@gmail.com
}

Received: November 17, 2019 Accepted: January 31, 2020 Published: March 27, 2020

doi:10.5296/jsr.v11i2.15849 URL: https://doi.org/10.5296/jsr.v11i2.15849

\begin{abstract}
This Study is about Muslim cultural symbol in the tradition of tabur beras kuning in the wedding ceremony in Malang. This study aims at discussing the results of observation and in depth interview to the practitioners of tabur beras kuning tradition who still hold and practice this tradition in every wedding ceremony in Malang. This topic is interesting because there is a kind of acculturation between Islam and culture. Islam with its Islamic values has influenced tabur beras kuning tradition and it has worked for long time and it is still practiced up to now. Islamic values have colored the culture. This, further, brings to the arising of the Muslim cultural symbols. The Islamic values in tabur beras kuning tradition have affected people to depend on and get closer to God the Almighty so that the societies who do this tradition might always hope to live prosperously and peacefully. Therefore, it is important to maintain tabur beras kuning tradition so that this tradition would not be perishing in line with the coming of modern era.
\end{abstract}

Keywords: “Tabur beras kuning”, Islamic values, Muslim cultural symbols 


\section{Introduction}

Indonesia is a big country consisting of many tribes having various cultures. This cultural diversity owned by many Indonesian tribes has shown their own characteristics. This culture should be maintained and developed so that every region might keep its own cultural uniqueness. This cultural richness is a very good asset for the Indonesian country in term of enriching its national culture. Beside, in the Indonesian constitution, UUD 45, it is stated that the government would develop Indonesian culture in the midst of the world civilization by giving freedom for the societies to develop their culture. This means that it is necessary to maintain national culture as parts of the national richness.

One of the Indonesian cultures which still exist up to now is the tradition of tabur beras kuning. And one of the regions which still maintain and practice this culture is Malang, one of the cities located in East Java Indonesia. This tradition is commonly used to go along with wedding ritual. This ritual is believed to contain several values which are very useful for the people who practice it. Related to the existence of the life values in a culture, Koentjaraningrat (1984: 349-350) states that tradition is inheritance from the ancestors which is very important for individuals in having their daily lives so that this ritual might be learned. This ritual is a part of culture containing life values which would guide people in having their life. So, the Indonesian ancestors might have left tabur beras kuning tradition which have many life values to be learned to make its doers to have better life.

Di Java Indonesia, especially in Malang, this tabur beras kuning tradition is still well conserved. This is shown from the use of beras Kuning or yellow rice accompanying the process of wedding ceremony. The interesting thing of this tradition is the existence of Islamic values which have been acculturated with this tradition. Further, Islamic values have influenced and become the important part of this tradition in society. It seems that tabur beras kuning tradition would not work without the existence of Islamic values in it. It is in line to Supriyanto (2000: 1) who states that religion is commonly influencing societies' culture. In this case religion is used to complete the tradition or culture done by the society. Thus, Islamic values which have experienced an acculturation process with the tabur beras kuning have very big roles in the process of wedding ceremony and they are even used as the media to communicate to God the Almighty.

This tabur beras kuning tradition is important to be done because in several places this tradition has been rarely done by the society, they are even almost perished and to be forgotten by the Indonesian young generation. There are some factors which might influence it and one of them is due to the modernization. Modernization which might impact to the fast growing of the country in one side is a good thing; however, it might also impact to the Indonesian young generation to forget their national traditional culture. Thus, this study is meant to open societies' view that preserving this national culture is very important because in the national culture, one of them is tabur beras kuning tradition, cover several life values as the reflection of Islamic values. Thus, this study aims at discussing the result of observation and in-depth interview to some people doing this tabur beras kuning tradition accompanying wedding ceremony in several places in Malang, one of the regions in Indonesia which still maintains and conducts 
this tradition up to now. It is done by discussing and relating some research findings with some theories of symbolic communication, Islamic values, and some other related theories and research findings on tabur beras kuning tradition in the wedding ceremony happened in the society.

\section{Research Methodology}

This study is a qualitative research using phenomenology perspectives. Creswell (2013) stated that phenomenology is a qualitative research approach which focuses on the life experience of certain societies. The main goal of the approach is to get natural description of phenomena in the societies. In addition, Maleong (1989: 15) states that qualitative study is a study which cannot be separated from its contexts. This qualitative research is done based on several considerations such as it is based on some phenomena of tabur beras kuning done by the societies in Malang; besides, in this research the researcher is the main instrument. Next, phenomenology is done due to reach the research objective that is finding out and describing societies' understanding about tabur beras kuning tradition done in Malang East Java Indonesia. This study is done in several areas in Malang such as in Kesamben, Ngijo and Tegalgondo village which still hold and run this tabur beras kuning tradition accompanying wedding ceremonies. The subjects are chosen purposely based on their good understanding about this tradition. Data is collected through observation and in-depth interview. In this case the interviews have been done the ritual doers. It is in line to Creswell (2013) who stated that typically, the interviews should be done the individuals having first-hand knowledge of an event, situation or experience. Next, Analysis is done based on the on-going analysis: data analysis is done simultaneously and data found is compared with the data got earlier. In this case, the understanding toward the subject is known as the first order understanding (Sumaryono, 1993: 165-166). To check the data, several ways are done such as to lengthen the observation, and to use triangulation system and next to use member checking (Lincoln and Guba, 1985).

\section{Results and Discussion}

From the analysis, it is found that tabur beras kuning tradition has been conducted by the society in Malang East Java. This tradition is done as a part of the processes in wedding ceremony. This tabur beras kuning is done at least in the two processions: sawuran and kacar kucur. Sawuran is one of the processions in wedding ceremony which is done to welcome the bridegroom and his families coming to the bride's house. This sawuran tradition is done by spreading yellow rice to the bridegroom and his families attending the wedding ceremonies. The spreading of yellow rice is accompanied by reading shalawat nabi by the bride's families followed by the bridegroom and his families. This is in line to Sita, Kus and Ri as the subjects who stated that sawuran is done in the wedding procession. This sawuran ritual is done by spreading yellow rice to the bridegroom and his families. Next, it is also done by reading shalawat Nabi by the bride and her families followed by the bridegroom and his 
families. They also stated that this sawuran tradition is very important in the wedding ceremony and it has been doing from generation to generation.

From the finding above, it might be concluded that tabur beras kuning tradition had been done by Malang society in the form of sawuran ritual. This is done by spreading yellow rice to the bridegroom and his families along with the wedding ceremonies. This tradition has been done since long time ago. This sawuran tradition is very symbolic. Christiansen and Kirby (2003) stated that symbols are regarded the signifier that represent meaning (signified). Symbols might present in certain forms, such as auditory speech, words, characters in printed visual forms, physical objects, fashion and clothing, human individuals, and events. Next, any entities, natural or social, physical or mental, tangible or intangible might regarded as a symbol as far as they represent certain meaning. Related to the use of symbols in a ceremony, Geertz (1973) stated that some symbolic forms might be used by people to communicate, enliven and develop their knowledge about attitudes toward lives. These symbols have certain meanings. In addition, Sarman (2012) stated that tabur beras kuning tradition has been done since long time ago. This tradition is used in several processions and in various human's activities since their birth up to their death. In India, tabur beras kuning is done in the Purin and Holi and they are done as the symbol of glory from evil. This tradition is done by spreading yellow rice as the symbol of fertility.

Next, sawuran tradition is regarded to be a sacred tradition. In Indonesia, sawuran tradition is done in several regions in various traditions. In these various traditions, the use of rice, either yellow or white rice, as symbols is having several meanings. Generally, they are containing good hopes. For example, in Sumatera, there is a tradition named by tepung tawar. In this tradition, two kinds of colorful rice are used, they are white rice and yellow rice. This colorful rice symbolizes a balance in human's life, such as there is a night and a day, god and bad, man and woman, etc. In Java, sawuran is also done in tedak siti ritual. This ritual is done to welcome a newly born baby and it is done by spreading yellow rice mixed by money in coins to be grasped by many children. This ritual contains a hope that the baby would become a generous person in the future. In Banjarmasin, South Kalimantan, there is also tradition of giving yellow rice to the baby or children who always get the disturbance from the evil spirits. This yellow rice is believed to be able to protect the children from this evil spirit that would disturb or haunt children. Next, in the Central Kalimantan, there is tabur beras kuning tradition known as ngiring tamui done by Dayak tribes. This ritual is done by Dayak leader by reading sacred words, mantra. This yellow rice is used to connect humans with the nature. In Dayak Kanayatan, there is tradition known as baras banyu. This is rice mixed by Tengkawang oil so that the rice color might become yellow. In general, tabur beras kuning tradition is used in the wedding ceremony. This tradition is done to welcome bridegroom and his families who have just come to the bride's house. It is done by spreading yellow rice to the bridegroom and his families while reading Shalawat Nabi. In this case, yellow rice is used to symbolize prosperity and happy life (Sarman, 2012). Related to the use of either yellow or white rice having certain symbols, Hawkins (1973) stated that a symbol is something that one says or does and this thing might have several meaning. Thus, it is clear that the use of rice in several ceremonies in some areas in Indonesia might be symbolic and containing several meanings. 
Another ritual that has used yellow rice as its medium in the wedding ceremony is kacar kucur. This kacar kucur ritual is one of the processions in wedding ceremony. It is done by putting some ingredients like yellow rice, coins, several kinds of peanuts, and also telon flowers in a piece of fabric. Next, these ingredients would be poured by the bridegroom to be accepted by the bride in a piece of sindur. Related to the tradition of kacar kucur, all the subjects, Sita, Kus and Ri agree that kacar kucur is done after sawuran tradition and it is done by pouring yellow rice including some other ingredients by the bridegroom to be accepted by the bride. This is in line to Sarman (2012) who stated that beside sawuran, yellow rice is also used in kacar kucur as a part of wedding ceremony in Java. This procession is done by the bridegroom by pouring Raja kaya in a piece of fabric and accepted by the bride in a piece of sindur. The ingredients poured by the bridegroom cover yellow rice, coins, several kinds of peanuts and also telon oil. This tradition means that the bridegroom would be responsible to fulfill family's needs. Next, Raja kaya which is poured by the bridegroom might not be dropped. This means that the bride would be able to keep and manage the wealth given by the husband. Related to the meaning of kacar kucur for the family, Bramantyo (2017) stated that kacar kucur means that the bridegroom would be responsible in term of working to look for the families' wealth and the bride would manage the families' need as well as possible. In addition, Eny (2011) states that kacar kucur means that the bridegroom gives the income to the bride in the forms of coins and other ingredients to symbolize bridegroom's responsibility to the family. Di Sunda, There is a tradition like kacar kucur known as saweran. Saweran is done by spreading yellow rice and coins both to the bride and bridegroom. However, it is only the rice which is spreaded and the coins are let in the can. This tradition is done accompanied by listening Sunda songs directed to the couple. This tradition means that the couple would be successful and to be loved by the other family members. (Sarman, 2012).

Related to symbolic communication, it is found that tabur beras kuning tradition in wedding ceremony has several forms of symbolic communications. Hawkins (1973) stated that symbolic communication is the exchange of messages that change a priori hopes of events. Next, Christiansen and Kirby (2003) stated that symbolic communication in humans might use a system of arbitrary symbols in which its definition and function are agreed by the society using it. Next, it is found both in the tradition of sawuran and kacar kucur, the societies interact each other in the form of symbolic communication using yellow rice as its objects hoping that God would bless their hopes. This is in line to Blumer (1969) who states that interaction consists of several humans' activities and symbolic communication is the interpretation of humans' activities. Thus, through the tradition of sawuran and kacar kucur, societies have interacted each other to create a meaningful life. In addition, Soeprapto (2002) states that the experts of symbolic communication like William James, James M. Baldwin, John Dewey, George Herbert Mead, Charles Horton Cooley, William I. Thomas, Kuhn and Herbert Blumer have agreed that to use symbolic communication to describe activities of social structure or societies who interact each other. In this case, people are communicating each other using symbols to construct the society.

In the sawuran tradition in the wedding ceremony, symbolic communication is found in the form of spreading yellow rice to the bridegroom and his families when they are coming to the 
bride's house. In line with spreading yellow rice, Shalawat Nabi is sung by the bride and her families and followed by the bridegroom and his families. Next, in kacar kucur tradition, symbolic communication is found in the form of pouring raja kaya covers yellow rice, coins, several kinds of peanuts, and telon oil done by the bridegroom very carefully which is going to be accepted by the bride in a piece of sindur fabric. Thus, tabur beras kuning tradition has become a means of interaction for the societies in the wedding ceremony and this tradition is rich of meaning and very significant for the society. It is because the use yellow rice in tabur beras kunig tradition might symbolize prosperity and happy life. And because of this significance this tradition is very importance for the society. Related to the use of yellow rice and other ingredients as means of communication of the societies, Jaelani (2012) states that humans' interaction in the community is commonly well planned, formal, or non-formal, and it might arise in several forms. Active communication in the societies is colored by many cultural symbols which are rich of meanings. This symbolic interaction in the society might appear in several forms both in verbal or nonverbal forms. For example, the use of a hand phone and internet is the symbol of modern man.

Related to the importance of the meaning of symbol in one ritual, the societies has believed and maintained that symbol in one of the symbolic interactions in the society conserved in certain cultural precession. This is in line to Buck dan Vanlear (2002) stating that symbol is important for the society. People believe that the use of symbol in their life might help them reach their dreams and hopes. Symbolic communication is believed and done by the society to reach their life goals. Thus, the existence of symbols is very importance for the society. The use of tabur beras kuning in the wedding ceremony using several ingredients is believed to be able to help the societies fulfill their dreams. This makes societies willing to preserve culture having significant symbols. And they even have become symbolic societies. They have used symbols as parts of culture to reach their dreams and to maximize their life. As the example is the use of tabur beras kuning tradition in the wedding ceremony especially in the rituals of sawuran and kacar kucur. Thus, tabur berang kuning tradition in the society is rich of meaning which might contain societies' hopes. Symbols might show their existence. This is in line to Gumilar (2008) stating that symbol might represent ones' identity or characteristics. In the case of Tato in one's body, it might represent art and beauty. Next, Hariyati (2012) states that the ownership of one thing might symbolize one's existence, for example the importance of hand phone for the people living in the city is very significant as it might show about modernity and also prestige at the same time.

Related to the Muslim cultural symbols in the ritual of tabur beras kuning, this can be found in the use Shalawat Nabi and several kinds of Muslim praying along tabur beras kuning tradition both in sawuran and kacar kucur ritual. Thus, there is an acculturation between Islam and culture. The acculturation between the culture and Islam happened when some Muslim's prays are used during the ritual process of a culture. In this case, Islam has influenced the culture. This brings the culture to have some Islamic characteristics and it is actualized in the use of Islamic prays during the procession of rituals in culture. The influence of Islam has made societies conduct the rituals as well as possible. They even enjoy to have the rituals as this culture is very symbolic. It is containing about praying to the God that might help them reach 
their hopes and dreams. Just like in the case of tabur beras kuning, this culture has been blended with Islamic values. This makes the societies accept and enjoy the culture and they are even happy to maintain the culture. This culture is rich of symbols as it has been blended by Islamic values which show Islamic characteristics that might be called as Islamic cultural symbols. And this happened in the case of sawuran and kacar kucur procession in the tabur beras kuning tradition. The societies believe that sawuran tradition followed by the reading of Shalawat nabi might bring the couples to be easy to reach their dream as they would get God's bless. This belief is the reflection of one's faith to God the Almighty. So, based on the faith to God that they have, societies would carry out the tradition happily with the hopes they will get God's bless. People believe that faithfulness to God might bring societies to reach many kinds of goodness. For example, they might become individuals who are serious in doing good deeds (QS. Al Hujurat:7-8), they might get happiness worldly and heavenly (QS. An Nahl: 97), they might be saved from the hell (QS. Al Qiyamah: 22-23), they might become people who is strong in their faith (QS. Ibrahim:27) (http://asysyariah.com/taqwa-dan-keutamaannya/). Next, related to the Islamic values, Madjid (2008) in Djamal (2017) states that iman is mental attitude to only believe in God, the Almighty. Iman is discussed more in tauhid. Tauhid is devided into four: Ar-rububiyyah, Al-Uluuhiyah, Al-asmaa' wa Ash-Shifaat, Al-Mulkiyah.Ar-Rububiyyah (Allah/ God as the Creator), Al-Uluuhiyah (Allah/ God as the only One to worship), Al-asmaa' wa Ash-Shifaat (Allah/God with His names and characteristics), and Al-Mulkiyah (Allah/God as the Almighty). Further, the application of these Islamic values in several cultural phenomena, like the one in tabur beras kuning tradition has become Muslim cultural symbols and it is believed that the societies who practice this culture might bring them to have happy life.

\section{Conclusion}

From the discussion above, it might be concluded that tabur beras kuning tradition especially in sawuran dan kacar kucur tradition is still done along with the procession of weeding ceremony held in several areas in Malang. In line with tabur beras kuning procession, Islamic values have been used and even become an important part to succeed the wedding ceremony. The application of Islamic values in this culture has brought to the coming of Muslim cultural symbols. In this case, societies tend to preserve and do their traditions or culture that has been blended with Islamic values happily. They believe that by doing tabur beras kuning tradition in the wedding ceremony accompanied by the application of Islamic values, they might reach their good hopes such as prosperity, success, happiness in their life, etc.

\section{References}

Asy, S. 17 Keutamaan Iman dalam Islam. Retrieved from http://asysyariah.com/taqwa-dan-keutamaannya/

Blumer, H. (1969). Symbolic interactionism. Englewood Cliffs, NJ: Prentice-Hall.

Bogdan, R., \& Sari K. (2010). Qualitative Research for Education: An Introduction to 
Theories and Methods (5th ed.). Boston: Pearson.

Buck, R., \& Vanlear, A. (2002). Verbal and non verbal communication: Distinguishing Symbolic, Spontanous, and Pseudospontanous Non Verbal Behavio. Journal of Communication, 52(3), 522-541. https://doi.org/10.1111/j.1460-2466.2002.tb02560.x

Creswell, J. W. (2013). Qualitative Inquiry \& Research Design: Choosing Among the Fives Approaches. Thousand Oaks, CA: SAGE Publication, Inc. (pp. 77-83) in blog. Baruch. cuny. edu.

Christiansen, M. H., \& Kirby, S. (2003). Language Evolution: Consensus and Controversies. $\begin{array}{llll}\text { Trends in } \quad \text { Cognitive } & \text { 300-307. }\end{array}$ https://doi.org/10.1093/acprof:oso/9780199244843.001.0001

Geertz, C. (1973). The Interpretation of Culture. Basic Books 2000. Retrieved from https://en.Wikipedia.org/Wiki/CliffordGeertz

Gumilar, G. (2008). Makna Komunikasi Simbolik di Kalangan Pengguna Tato Kota Bandung. Mediator, 9(1), 51-62. https://doi.org/10.29313/mediator.v9i1.1140

Hariyati. (2012). Studi Interaksionisme Simbolik: Budaya Telepon Genggam pada Masyarakat Perkotaan. Jurnal Penelitian Komunikasi, 10(1).

Hawkins, D. (1973). Model of Symbolic communication. Journal of Advertising Research, 13(3), 33-38.

Jailani, M. S. (2012). Interaksi Simbolik, Konstruktivisme, Teori Kritis, Postmodernisme dan Post-Strukturalisme. Edu-bio, 3.

Koentjaraningrat. (1984). Kebudayaan Jawa. Jakarta: PT Balai Pustaka.

Djamal, S. M. (2017). Penerapan Nilai Nilai Ajaran Islam dalam Kehidupan Masyarakat di desa Garuntung Kecamatan Kindang Kabupaten Bulukamba. Jurnal Adabiyah, 17(2), 217. https://doi.org/10.24252/JAd.v17i1i2a5

Maleong, L. J. (1989). Metodologi Penelitian Kualitatif. Bandung: Rosda Karya Pasal 32 ayat 1 Amandemen UUD 45

Sarman, S. (2012). Wisata Religi. Retrieved from http://parigalwisata.blogspot.com/2012/12/tradisi-beras-kuning.htm

Soeprapto, R. (2002). Interaksi Simbolik, Perspektif Sosiologi Modern. Yogyakarta: Pustaka Pelajar.

Supriyanto, H. (2000). Upacara Adat Jawa Timur. Surabaya: Dinas Pendidikan dan Kebudayaan. 


\section{Copyright Disclaimer}

Copyright for this article is retained by the author(s), with first publication rights granted to the journal.

This is an open-access article distributed under the terms and conditions of the Creative Commons Attribution license (http://creativecommons.org/licenses/by/3.0/). 